\title{
Effects of Enhanced-Efficiency Nitrogen Fertilizers on Soil Microbial Biomass and Respiration in Tropical Soil Under Upland Rice Cultivation
}

\author{
Vinícius Almeida Oliveira ${ }^{1}$, Eliana Paula Fernandes Brasil ${ }^{2}$, Welldy Gonçalves Teixeira ${ }^{2}$, \\ Felipe Corrêa Veloso dos $\operatorname{Santos}^{3} \&$ Atila Reis da Silva ${ }^{4}$ \\ ${ }^{1}$ Faculdade UNA, Jataí, GO, Brazil \\ ${ }^{2}$ Federal University of Goiás, Goiânia, GO, Brazil \\ ${ }^{3}$ School of Engineering, Pontifcal Catholic University of Goiás, Goiânia, GO, Brazil \\ ${ }^{4}$ Federal Institute Goiano, Campos Belos, Goiânia, GO, Brazil \\ Correspondence: Welldy Gonçalves Teixeira, Campus Samambaia, Agronomy School, Federal University of \\ Goiás, Goiânia, Goiás, Brazil. E-mail: welldygteixeira@gmail.com
}

Received: October 14, 2020

Accepted: February 27, 2021

Online Published: May 15, 2021

doi:10.5539/jas.v13n6p31

URL: https://doi.org/10.5539/jas.v13n6p31

\begin{abstract}
While over-use of $\mathrm{N}$ fertilizers can suppress microbial biomass, application of urease inhibitors is known to be a potential way to rebuilt microbial diversity and improve soil functions. However, the hypothesis of this study is that the application of $\mathrm{N}$ fertilizers regardless of the source would increase soil microbial biomass and reduce soil respiration. A two-year field experiment was conducted to assess the effects of enhanced-efficiency $\mathrm{N}$ sources on soil microbial biomass, and soil respiration. The experiment was set up in a randomized block design in a $3 \times 4+1$ factorial scheme, with four replicates. Treatments comprised three sources (conventional uncoated urea, NBPT (N-(n-butyl) thiophosphoric triamide)-treated urea, and polymer-coated urea) and four rates $(30,60$, 90 and $120 \mathrm{~kg} \mathrm{ha}^{-1}$ ) of $\mathrm{N}$, in addition to a control treatment (no fertilizer application). Microbial biomass $\mathrm{C}$ (MBC) and microbial biomass $\mathrm{N}(\mathrm{MBN})$, and soil respiration $\left(\mathrm{C}_{-}-\mathrm{CO}_{2}\right.$ and $\left.q \mathrm{CO}_{2}\right)$ were determined in upland rice rhizosphere in each crop season. Responses of soil microbial properties to $\mathrm{N}$ fertilization were dependent on the $\mathrm{N}$ rates, but no significant effect of the $\mathrm{N}$ sources was observed. All measured parameters, except $\mathrm{MBC}$ in the first season and $\mathrm{C}-\mathrm{CO}_{2}$ in the second season, were increased with increasing $\mathrm{N}$ rates. However, the application of $\mathrm{N}$ higher than $60 \mathrm{~kg} \mathrm{ha}^{-1}$ suppressed soil microbial biomass, as well as soil respiration. Therefore, the lack of response by added urease inhibitors to the $\mathrm{N}$ sources indicate that optimizing $\mathrm{N}$ rates for upland rice production is a far more effective option for improving soil microbial community than using enhanced-efficiency $\mathrm{N}$ sources.
\end{abstract}

Keywords: soil microbial activity, fertilizer efficiency, $\mathrm{N}$ rate

\section{Introduction}

Nitrogen $(\mathrm{N})$ is one of the most important elements in natural and agricultural ecosystems (Krivtsov et al., 2011). Increased $\mathrm{N}$ input has been a major contributor to higher crop yields over the last decades. In fact, the $\mathrm{N}$ availability directly influence the growth and abundance of microorganisms, which play a critical role in nutrient cycling and maintenance of soil structure for improved plant production. However, the $\mathrm{N}$ addition to agricultural fields can negatively affect microbial communities and restrict crop productivity depending on many factors, such as fertilizer type, $\mathrm{N}$ rate, soil $\mathrm{pH}$, soil texture, and the crop (Lupwayi et al., 2012).

Previous studies reported that $\mathrm{N}$ fertilizers can have no effect or act either positively or negatively on soil microorganisms (Lupwayi et al., 2012; Yu et al., 2018). Li et al. (2013) found that microbial activity decreased in soils with increasing $\mathrm{NH}_{4}{ }^{+}-\mathrm{N}$ concentration under application of ammonium sulfate and urea, suggesting that microbial functional diversity can occur with a $\mathrm{N}$ gradient. Zhalnina et al. (2015) reported that the application of ammonium-based fertilizers decreased soil $\mathrm{pH}$, thus reduced microbial abundance because some species cannot tolerate acidic environment. In contrast, Liu et al. (2020) found that the content of microbial biomass C (MBC) and $\mathrm{N}(\mathrm{MBN})$ in the rhizosphere soil were increased following fertilizer applications. 
Besides the contradictory influence of $\mathrm{N}$ fertilizers on the soil microbial biomass, the use of inorganic $\mathrm{N}$ fertilizers is essential in agricultural systems. To ensure that the addition of $\mathrm{N}$ fertilizer is beneficial to both crop production and soil microorganisms, effort has been put into finding ways to improve fertilizer $\mathrm{N}$ use efficiency and minimizing environmental impacts. Recommendations to enhance $\mathrm{N}$ use efficiency include the use of formulated forms of fertilizer containing urease and nitrification inhibitors to reduce $\mathrm{NH}_{3}$ volatilization from urea hydrolysis (Engel et al., 2019). The application of urease inhibitors can reduce volatilization by temporarily preventing urease from breaking down urea, thereby leaving more $\mathrm{NH}_{3} / \mathrm{NH}_{4}{ }^{+}$available for plants to take up (Chien et al., 2008; Gioacchini et al., 2002).

The effect of urease inhibitors on urea hydrolysis and enhanced $\mathrm{N}$ use efficiency has been widely investigated. However, the impact of different $\mathrm{N}$ fertilizers containing urease inhibitors on soil microbial properties is still an open question. A two-yr field experiment was conducted to assess the effects of the widely used urease inhibitor, $\mathrm{N}$-(n-butyl) thiophosphoric triamide (NBPT) and polymer-coated urea (PCU) on soil microbial biomass, and soil respiration. The hypothesis of this study is that the application of $\mathrm{N}$ fertilizers regardless of the source would increase soil microbial biomass and reduce soil respiration.

\section{Materials and Methods}

\subsection{Experimental Site}

The field experiment was carried out in two growing seasons (2013/14 and 2014/15) in an area $\left(16^{\circ} 35^{\prime} 50^{\prime \prime}\right.$ S; $49^{\circ} 16^{\prime} 40^{\prime \prime} \mathrm{W} ; 735 \mathrm{~m}$ a.s.1.) located in the Agronomy College at the Federal University of Goiás, State of Goiás, Brazil. The local climate is classified as Aw (seasonal tropical savanna), with a humid season from October to April and a dry one from May to September according to the Köppen classification. The average annual precipitation is $1500 \mathrm{~mm}$, and the mean annual temperature is around $22.5^{\circ} \mathrm{C}$.

The soil was classified as typic dystrophic Red Latosol (LVd) in the Brazilian Soil Classification System (Santos et al., 2013), which corresponded to an Oxisol in the US Soil Taxonomy System [11]. Soil samples for characterization were collected from the 0 - to $20-\mathrm{cm}$ depth layer before the $\mathrm{N}$ fertilizer rates were applied using an auger. Prior to characterization, the samples were air dried and sieved through a 2-mm mesh and then analyzed following methodologies as proposed by Embrapa (1997, 2009). Some selected soil chemical properties and particle size distribution are given in Table 1.

Table 1. Selected chemical properties and particle size distribution of the soil at the experimental site

\begin{tabular}{|c|c|c|c|c|c|c|c|c|c|}
\hline \multicolumn{10}{|c|}{ Chemical analysis } \\
\hline $\mathrm{pH}_{\mathrm{Ca}}$ & $\mathrm{Ca}^{2+}$ & $\mathrm{Mg}^{2+}$ & $\mathrm{K}^{+}$ & $\mathrm{Al}^{3+}$ & $\mathrm{H}+\mathrm{Al}$ & $\mathrm{CEC}$ & $\mathrm{V}$ & $\mathrm{P}$ & $\mathrm{OM}$ \\
\hline \multirow[b]{2}{*}{5.58} & \multicolumn{6}{|c|}{--- $\mathrm{cmol}_{\mathrm{c}} \mathrm{dm}^{-3}$} & $\%$ & $\mathrm{mg} \mathrm{dm}{ }^{-3}$ & $\mathrm{~g} \mathrm{dm}^{-3}$ \\
\hline & 2.15 & 1.05 & 0.312 & 0 & .63 & 6.14 & 57.46 & 4.88 & 17.5 \\
\hline \multicolumn{10}{|c|}{ Textural analysis } \\
\hline \multicolumn{3}{|l|}{ Sand } & \multicolumn{2}{|c|}{ Silt } & & & \multicolumn{3}{|l|}{ Clay } \\
\hline \multicolumn{10}{|l|}{------- } \\
\hline
\end{tabular}

Note. $\mathrm{pH}_{\mathrm{Ca}}$ : $\mathrm{pH}$ measured in $0.01 \mathrm{~mol} \mathrm{~L}^{-1} \mathrm{CaCl}_{2}(1: 2.5) ; \mathrm{Ca}^{2+}, \mathrm{Mg}^{2+}$, and $\mathrm{Al}^{3+}$ extracted by $1 \mathrm{~mol} \mathrm{~L}^{-1} \mathrm{KCl}$; $\mathrm{P}$ and $\mathrm{K}$ extracted by $0.05 \mathrm{~mol} \mathrm{~L}^{-1} \mathrm{HCl}+0125 \mathrm{~mol} \mathrm{~L}^{-1} \mathrm{H}_{2} \mathrm{SO}_{4}$ (Mehlich-1 extractor); $\mathrm{H}+\mathrm{Al}$ extracted by $0.5 \mathrm{~mol} \mathrm{~L}{ }^{-1}$ calcium acetate buffered at $\mathrm{pH}$ 7; CEC: cation exchange capacity; V: base saturation; OM: organic matter, estimated from the organic carbon extracted by the Walkley-Black method. Textual Analysis conducted using the pipette method.

\subsection{Experimental Design and Treatments}

The experiment was set up in a randomized block design in a $3 \times 4+1$ factorial arrangement, with four replicates. Treatments comprised three sources (conventional uncoated urea, NBPT-treated urea, and PCU) and four rates $\left(30,60,90\right.$ and $\left.120 \mathrm{~kg} \mathrm{ha}^{-1}\right)$ of $\mathrm{N}$, in addition to a control treatment (no fertilizer application).

\subsection{Field Experiment}

Field was ploughed at $20 \mathrm{~cm}$ depth prior to seeding. Plots consisted of four 5 meters long rows, spaced $0.5 \mathrm{~m}$ apart, using the rice cultivar BRS Esmeralda, which has a moderate resistance to major diseases and a certain tolerance to water stress (Castro et al., 2014). Additionally, BRS Esmeralda is a relatively recent upland rice 
cultivar developed by the breeding program coordinated by the Brazilian Corporation for Agricultural Research (Embrapa). The higher performance of BRS Esmeralda compared to other current cultivars is due to its high grain quality, good drought tolerance, high disease resistance and lodging resistance (Colombari et al., 2013). Further, this cultivar has a great stability and adaptability to a large range of soils, climates, and crop management on the Cerrado region, which may lead to a satisfactory yield performance in this study.

The net plot area was composed of the two central rows, considering the lateral rows as borders. The soil was prepared in both years by one plowing and one disk harrow leveling. The seeds of rice were sown manually 20 $\mathrm{cm}$ spaced apart in rows, with two or three seeds per hole. Nitrogen fertilizers were applied manually in two split doses: $50 \%$ at the seedling stage, and $50 \%$ at the tillering stage ( $\sim 80 \mathrm{~d}$ after sowing). All treatments received 400 $\mathrm{kg} \mathrm{ha}^{-1}$ of the formula $00-20-20$ as a basal fertilizer to supply phosphorus and potassium. Weed management consisted of hand weeding plots two times during the growing season. Rice was harvested in every growing season at the end of maturing stage (between 103 and $108 \mathrm{~d}$ after sowing).

\subsection{Soil Sampling}

At flowering stage, soil samples were collected from five points randomly at the $0-10 \mathrm{~cm}$ depth between the rows in each experimental plot at three different points to form a composite sample per replicate. The samples were homogenized using a $2 \mathrm{~mm}$ mesh sieve and prepared for microbial analysis. All samples were immediately stored in sealed plastic bags in a cooler and transported to laboratory and stored at $4{ }^{\circ} \mathrm{C}$. All microbiological determinations were conducted within $3 \mathrm{~d}$ of sampling.

\subsection{Microbial Biomass Measurements}

Prior to microbial biomass measurements, the soil moisture was adjusted to about $80 \%$ water holding capacity. The chloroform fumigation extraction and measurements of soil microbial biomass $\mathrm{C}(\mathrm{MBC})$ and $\mathrm{N}(\mathrm{MBN})$ in fumigated and non-fumigated soil extracts were performed following Vance et al. (1987). Samples of $20 \mathrm{~g}$ of dry weight equivalent of soil was fumigated with ethanol-free chloroform $\left(\mathrm{CHCl}_{3}\right)$ at $25^{\circ} \mathrm{C}$ for $24 \mathrm{~h}$. Both fumigated and non-fumigated soils were separately extracted with $80 \mathrm{~mL}$ of $0.5 \mathrm{~mol} \mathrm{~L}^{-1} \mathrm{~K}_{2} \mathrm{SO}_{4}$ by shaking for $40 \mathrm{~min}$ on a reciprocating shaker at 180 cycles per minute and then filtered using slow quantitative filter paper (Whatman No. 42).

An aliquot of the filtered extract $(8 \mathrm{~mL})$ was refluxed with $0.5 \mathrm{~mol} \mathrm{~L}^{-1} \mathrm{~K}_{2} \mathrm{Cr}_{2} \mathrm{O}_{7}(2 \mathrm{~mL})$, and $15 \mathrm{~mL}$ of a mixture containing $\mathrm{H}_{2} \mathrm{SO}_{4}$ and $\mathrm{H}_{3} \mathrm{PO}_{4}(2: 1 \mathrm{v} / \mathrm{v})$ in glass flasks. The mixture was burned at $100{ }^{\circ} \mathrm{C}$ for $30 \mathrm{~min}$. Cold blank was not heated. Samples were then cooled and diluted to $50 \mathrm{~mL}$ with deionized water. The residual dichromate was measured by back titration with $0.4 \mathrm{~mol} \mathrm{~L}^{-1}$ ferrous ammonium sulphate solution using ferroin as an indicator. Soil organic $\mathrm{C}$ (extracted org-C) in the extracts was measured by the titration technique using the following equation:

$$
\text { Extracted org- } \mathrm{C}=\frac{(\mathrm{H}-\mathrm{S}) \times \mathrm{M} \times \mathrm{D} \times \mathrm{E} \times 1,000}{\mathrm{C} \times \mathrm{A}} \times \frac{\mathrm{K}}{\mathrm{W} \times \mathrm{dwt}}\left(\mathrm{mg} \mathrm{g}^{-1} \text { dry soil }\right)
$$

where, $\mathrm{H}=$ titration solution consumed by the hot (refluxed) blank $(\mathrm{mL}), \mathrm{S}=$ titration solution consumed by the sample $(\mathrm{mL}), \mathrm{C}=$ titration solution consumed by the cold (unrefluxed) blank $(\mathrm{mL}), \mathrm{M}=$ normality of the $\mathrm{K}_{2} \mathrm{Cr}_{2} \mathrm{O}_{7}$ solution, $\mathrm{D}=$ volume of $\mathrm{K}_{2} \mathrm{Cr}_{2} \mathrm{O}_{7}$ solution added to the reaction mixture $(\mathrm{mL}), \mathrm{A}=$ aliquot of the extract $(8 \mathrm{~mL}), \mathrm{E}=3$ (conversion of $\mathrm{Cr}^{\mathrm{VI+}+}$ to $\left.\mathrm{Cr}^{\mathrm{II+}+}\right), \mathrm{K}=$ volume of the extractant $(\mathrm{mL})$ and dwt $=$ dry weight of moist soil per gram. Microbial biomass $\mathrm{C}(\mathrm{MBC})$ was determined as follows:

$$
\text { Soil MBC }\left(\mathrm{mg} \mathrm{kg}^{-1} \text { dry soil }\right)=(\mathrm{CF}-\mathrm{CNF}) / \mathrm{KEC}
$$

where, $\mathrm{CF}$ is the extracted organic-C from fumigated sample, CNF is the extracted organic-C from the unfumigated sample, and KEc is the calibration factor (0.38) as proposed by Wardle (1994).

Microbial biomass $\mathrm{N}(\mathrm{MBN})$ was also examined by the fumigation-extraction technique. As such, fumigated and non-fumigated soil samples were extracted with $\mathrm{K}_{2} \mathrm{SO}_{4}$ and the filtered extract was measured for total $\mathrm{N}$ by using the Kjeldahl digestion procedure. For digestion, $1.0 \mathrm{~g}$ of soil was digested with a digestion mixture $\left(\mathrm{K}_{2} \mathrm{SO}_{4}: \mathrm{CuSO}_{4}: \mathrm{Se}\right)$ at the ratio of 1:0.1:0.01, and $3.0 \mathrm{~mL}$ of concentrated $\mathrm{H}_{2} \mathrm{SO}_{4}$ in each digestion tube at $80^{\circ} \mathrm{C}$ for $12 \mathrm{~h}$. After digestion, the mixtures were carried out for distillation by pouring the samples into the steam distillation chamber of Kjeldahl with $10 \mathrm{~mol} \mathrm{~L}^{-1} \mathrm{NaOH}$ and $2 \% \mathrm{H}_{3} \mathrm{BO}_{3}$. Then, samples from the distillation chamber were titrated against $0.0025 \mathrm{~mol} \mathrm{~L}^{-1} \mathrm{H}_{2} \mathrm{SO}_{4}$. Microbial biomass $\mathrm{N}(\mathrm{MBN})$ was determined as follows:

$$
\text { Soil } \mathrm{MBN}=\left(\mathrm{mg} \mathrm{kg}^{-1} \text { dry soil }\right)=(\mathrm{NF}-\mathrm{NNF}) / \mathrm{KEN}
$$

where, NF is the extracted organic- $\mathrm{N}$ from fumigated sample, NNF is the extracted organic-N from the unfumigated sample, and KEN is the calibration factor (0.54) as proposed by Wardle (1994). 


\subsection{Basal Soil Respiration}

Soil respiration was determined by trapping the evolved $\mathrm{CO}_{2}$ from N-treated samples in $\mathrm{KOH}$. Briefly, soil samples of $20 \mathrm{~g}$ were incubated for $7 \mathrm{~d}$ at $25^{\circ} \mathrm{C}$ in $500 \mathrm{~mL}$ vessels containing $10 \mathrm{~mL}$ of $0.3 \mathrm{~mol} \mathrm{~L}^{-1} \mathrm{KOH}$. A vial containing $10 \mathrm{~mL}$ of $1 \mathrm{~mol} \mathrm{~L}^{-1} \mathrm{KOH}$ with the lid open to exclude $\mathrm{CO}_{2}$ evolved from the soil served as control to account for the $\mathrm{CO}_{2}$ trapped from the atmosphere. The concentration of $\mathrm{CO}_{2}$ trapped in the $\mathrm{KOH}$ solution was measured by titration with $0.1 \mathrm{~mol} \mathrm{~L}^{-1} \mathrm{HCl}$ against phenolphthalein after carbonate precipitation with $3 \mathrm{~mL}$ of $0.5 \mathrm{~mol} \mathrm{~L}^{-1} \mathrm{BaCl}_{2}$. Microbial metabolic quotient $\left(q \mathrm{CO}_{2}\right)$ was thereafter calculated as the ratio of basal respiration to MBC.

\subsection{Statistical Analysis}

Analysis of variance (ANOVA) was used to analyze the effects of $\mathrm{N}$ sources, $\mathrm{N}$ rates and their interaction on the microbial biomass pools, viz $(\mathrm{MBC}$ and $\mathrm{MBN})$, soil basal respiration $\left(\mathrm{C}-\mathrm{CO}_{2}\right)$, and metabolic quotient $\left(q \mathrm{CO}_{2}\right)$ from each growing season. Homogeneity of variances and normality tests were checked with the Bartlett's and Shapiro-Wilk tests. For qualitative factors (N sources), the means were compared by the Tukey's test at the $p<$ 0.05 level when the $\mathrm{F}$ test proved significant, whereas the quantitative factors $(\mathrm{N}$ rates) were submitted to regression analysis. Sigmaplot 10.0 was used to create graphs.

\section{Results and Discussion}

\subsection{Effects of N Fertilization on Biomass and Soil Respiration}

The effects of $\mathrm{N}$ treatments during the two growing seasons (2013 and 2014) of upland rice crop on soil microbial abundance and activity are presented in Table 2 . The enhanced-efficiency $\mathrm{N}$ fertilizers had no influence on the microbial soil properties at any growing season of the upland rice crop. On the other hand, the $\mathrm{N}$ rates significantly affected $(p<0.05)$ the $\mathrm{MBN}, \mathrm{C}-\mathrm{CO}_{2}$ and $q \mathrm{CO}_{2}$ in the first growing season (2013), whereas all microbial parameters except the $\mathrm{C}-\mathrm{CO}_{2}$ were affected by $\mathrm{N}$ rates in the second growing season (2014) (Table 2). No significant interaction effect of $\mathrm{N}$ sources and $\mathrm{N}$ rates occurred for the microbial parameters.

These results partially support the hypothesis of this study once soil microbial community was affected by $\mathrm{N}$ fertilization regardless of the $\mathrm{N}$ source. Ramirez et al. (2010) also found that the addition of different forms of $\mathrm{N}$ $\left(\mathrm{NH}_{4} \mathrm{NO}_{3},\left(\mathrm{NH}_{2}\right)_{2} \mathrm{CO}\right.$ (urea), $\left.\mathrm{KNO}_{3}, \mathrm{NH}_{4} \mathrm{Cl},\left(\mathrm{NH}_{4}\right)_{2} \mathrm{SO}_{4}, \mathrm{Ca}\left(\mathrm{NO}_{3}\right)_{2}\right)$ yielded a similar microbial response to three distinct soils, and demonstrated that a range of fertilizer types have the same impacts on soil respiration.

Table 2. Analysis of variance for the effects of enhanced-efficiency nitrogen fertilizers applied at different $\mathrm{N}$ rates on microbial biomass carbon $(\mathrm{MBC})$ and nitrogen $(\mathrm{MBN})$, basal respiration $\left(\mathrm{C}-\mathrm{CO}_{2}\right)$ and metabolic quotient $\left(q \mathrm{CO}_{2}\right)$ in two growing seasons (2013 and 2014) of upland rice (cultivar BRS Esmeralda)

\begin{tabular}{|c|c|c|c|c|c|}
\hline \multirow{2}{*}{ Source of variation } & \multirow{2}{*}{ DF } & \multicolumn{4}{|c|}{ MS } \\
\hline & & $\mathrm{MBC}$ & $\mathrm{MBN}$ & $\mathrm{C}-\mathrm{CO}_{2}$ & $q \mathrm{CO}_{2}$ \\
\hline \multicolumn{6}{|l|}{2013} \\
\hline $\mathrm{N}$ source $(\mathrm{S})$ & 2 & 13.17 & 9.90 & 0.60 & 0.00004 \\
\hline $\mathrm{N}$ rate $(\mathrm{R})$ & 4 & 207.22 & $167.28 * *$ & $4.53 *$ & $0.0003^{*}$ \\
\hline $\mathrm{S} \times \mathrm{R}$ & 8 & 161.59 & 6.31 & 1.82 & 0.0002 \\
\hline Residual & 42 & 123.99 & 4.49 & 31.46 & 0.00006 \\
\hline C.V. $\%$ & & 10 & 6.83 & 15.30 & 11.26 \\
\hline \multicolumn{6}{|l|}{2014} \\
\hline $\mathrm{N}$ source $(\mathrm{S})$ & 2 & 4.27 & 0.50 & 1.77 & 0.0003 \\
\hline $\mathrm{N}$ rate $(\mathrm{R})$ & 4 & $549.09 *$ & $95.28 * *$ & 2.11 & $0.0003^{\circ}$ \\
\hline $\mathrm{S} \times \mathrm{R}$ & 8 & 43.69 & 7.76 & 1.39 & 0.0002 \\
\hline Residual & 42 & 120.55 & 5.52 & 1.43 & 0.0002 \\
\hline C.V. $\%$ & & 9.95 & 7.50 & 14.20 & 16.12 \\
\hline
\end{tabular}

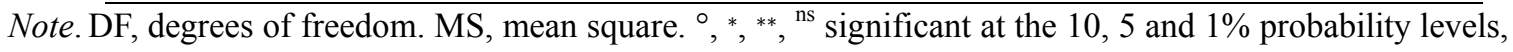
respectively.

\subsection{Soil Microbial Biomass}

Soil MBC and MBN were highly variable across the two growing seasons and ranged from 101.95 to $120.65 \mathrm{mg}$ $\mathrm{C} \mathrm{kg}^{-1}$ and 24.45 to $36.50 \mathrm{mg} \mathrm{N} \mathrm{kg}^{-1}$, respectively (Table 3). Nitrogen fertilizer treatments tended to increase soil microbial biomass with increasing $\mathrm{N}$ rate, as revealed by the highest values of $\mathrm{MBC}$ and $\mathrm{MBN}$ in the highest $\mathrm{N}$ 
rates compared with the control treatment (Table 3 ). The positive effect of $\mathrm{N}$ addition on soil microbial biomass has been reported by other authors (Zhou et al., 2012; Geisseler \& Scow, 2014; Geisseler et al., 2016).

In our study, the quadratic responses to $\mathrm{N}$ rates of $\mathrm{MBN}$ in the 2013 season (Figure 1a), as well as $\mathrm{MBC}$ and MBN in the 2014 season (Figures $2 \mathrm{a}$ and $2 \mathrm{~b}$ ), respectively, indicated from 75 to $214 \mathrm{~kg} \mathrm{~N} \mathrm{ha}^{-1}$ as the optimum rates for enhancing such properties. Hence, responses of soil microbial biomass were positive up to these $\mathrm{N}$ rates and negative thereafter, highlighting that microbial responses are more dependent on the rate of $\mathrm{N}$ application rather than the form of $\mathrm{N}$.

Most studies on the effects of $\mathrm{N}$ fertilizers on soil microorganisms examine only one $\mathrm{N}$ application rate. A large number of studies based on long-term field experiments have proved that optimum fertilizer $\mathrm{N}$ application to crops neither resulted in loss of organic matter nor adversely affected microbial activity in the soil (Zhang et al., 2008; Lupwayi et al., 2010; Lupwayi et al., 2011; Singh, 2018). In a 2-yr study with N applied as urea to barley and corn at soil-test recommended rates, Lupwayi et al. (2012) reported either no effect or a positive effect of $\mathrm{N}$ on MBC and bacterial diversity, and they concluded that $\mathrm{N}$ fertilizer effects depend on the $\mathrm{N}$ application rate. Furthermore, it is largely reported in literature that addition of $\mathrm{N}$ above than the optimum rates not only adversely influence soil biological communities but also increase residual inorganic $\mathrm{N}$, which can enhance $\mathrm{C}$ mineralization and lead to its loss (Singh, 2018). Therefore, the results reported here are in agreement with those reported in literature that fertilizer $\mathrm{N}$ applied at recommended rates probably does not cause negative effects on soil microorganisms.

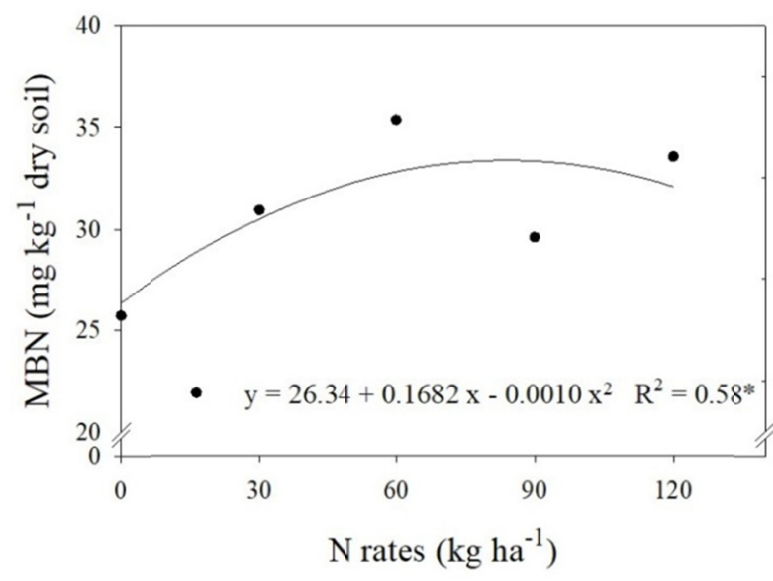

(a)

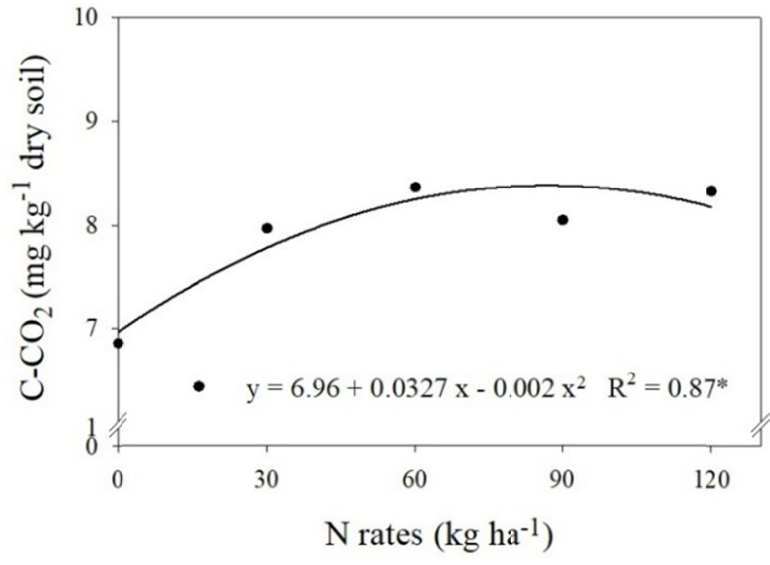

(b)

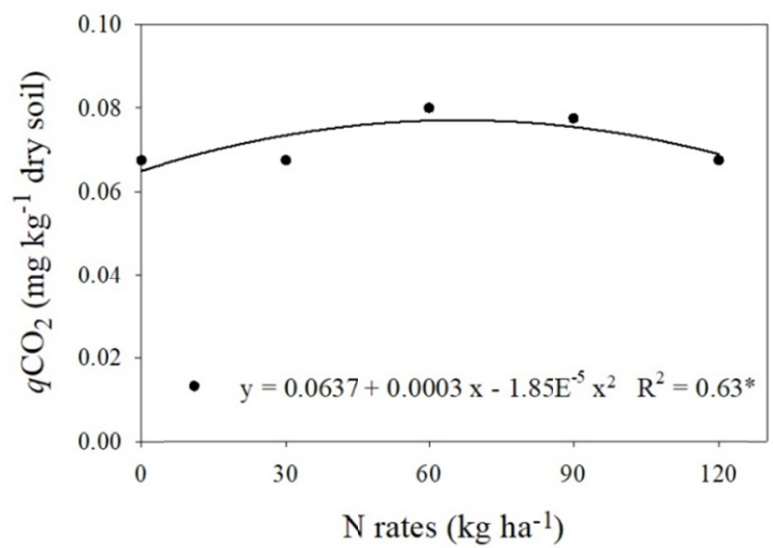

(c)

Figure 1. Effect of $\mathrm{N}$ application on (a) microbial biomass carbon (MBC), (b) microbial basal respiration $\left(\mathrm{C}-\mathrm{CO}_{2}\right)$, and (c) microbial metabolic quotient $\left(q \mathrm{CO}_{2}\right)$ in soil cultivated with upland rice (cultivar BRS Esmeralda) in the 2013 season 


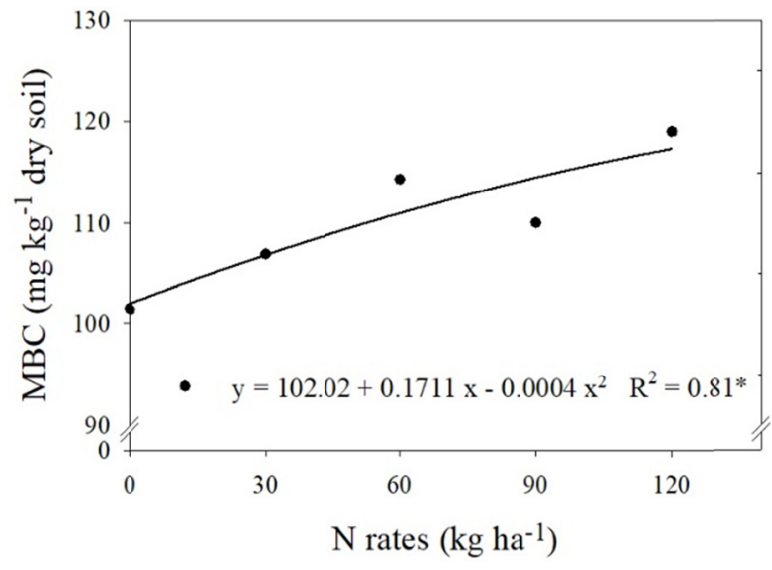

(a)

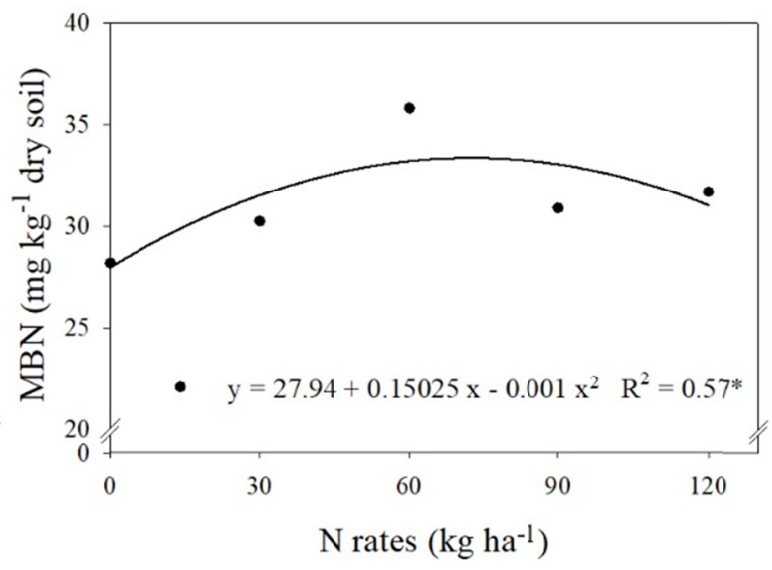

(b)

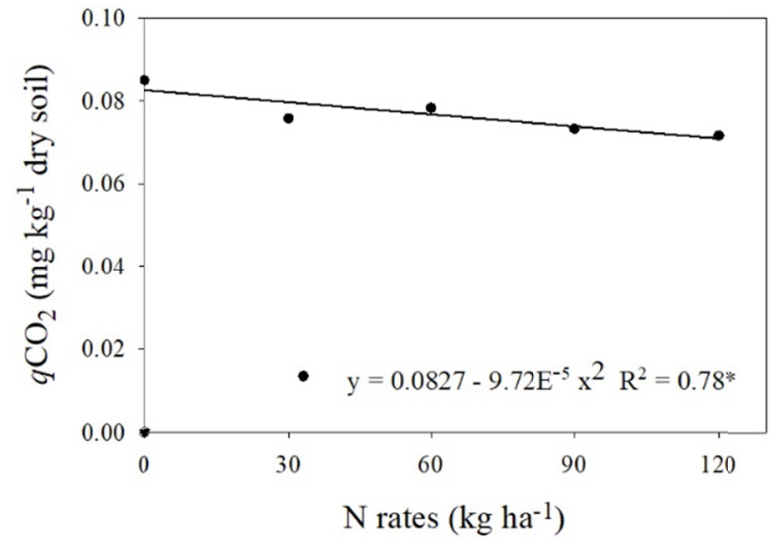

(c)

Figure 2. Effect of $\mathrm{N}$ application on (a) microbial biomass carbon (MBC), (b) microbial basal nitrogen (MBN), and (c) microbial metabolic quotient $\left(q \mathrm{CO}_{2}\right)$ in soil cultivated with upland rice (cultivar BRS Esmeralda) in the 2014 season

\subsection{Soil Microbial Respiration}

Basal respiration $\left(\mathrm{C}-\mathrm{CO}_{2}\right)$ and microbial metabolic quotient $\left(q \mathrm{CO}_{2}\right)$ followed a quadratic response to $\mathrm{N}$ rates in the 2013 season (Figures $1 \mathrm{~b}$ and 1c) and 2014 season in the case of $q \mathrm{CO}_{2}$ (Figure 2c). The values of $\mathrm{C}-\mathrm{CO}_{2}$ and $q \mathrm{CO}_{2}$ across the two growing seasons ranged from 6.58 to $9.70 \mathrm{mg} \mathrm{C}-\mathrm{CO}_{2} \mathrm{~kg}^{-1}$ and 0.058 to $0.095 \mathrm{mg}_{q} \mathrm{CO}_{2} \mathrm{~kg}^{-1}$, respectively (Table 3). Significantly lower values of $\mathrm{C}-\mathrm{CO}_{2}$ and $q \mathrm{CO}_{2}$ were observed in the unfertilized control as compared to the highest $\mathrm{N}$ treatments, indicating positive effect of $\mathrm{N}$ addition on soil microbial respiration. In addition, a positive effect of $\mathrm{N}$ enrichment rates below $60 \mathrm{~kg} \mathrm{~N}$ ha ${ }^{-1}$ on soil respiration was also observed, whereas $\mathrm{N}$ enrichment showed a negative effect at rates higher than $60 \mathrm{~kg} \mathrm{~N} \mathrm{ha}^{-1}$, indicating that a threshold $\mathrm{N}$ rate may occur for soil microbial respiration, which requires further study. 
Table 3. Absolute amounts of microbial biomass carbon (MBC) and nitrogen (MBN), microbial basal respiration $\left(\mathrm{C}-\mathrm{CO}_{2}\right)$, and microbial metabolic quotient $\left(q \mathrm{CO}_{2}\right)$ in soils cultivated with upland rice (cultivar BRS Esmeralda) in two growing seasons (2013 and 2014) under addition of enhanced-efficiency nitrogen fertilizers applied at different $\mathrm{N}$ rates

\begin{tabular}{|c|c|c|c|c|c|c|}
\hline \multirow{3}{*}{$\mathrm{N}$ rate $\left(\mathrm{kg} \mathrm{ha}^{-1}\right)$} & \multicolumn{6}{|c|}{ N sources } \\
\hline & \multicolumn{3}{|c|}{2013} & \multicolumn{3}{|c|}{2014} \\
\hline & UU & PCU & NBPT & UU & $\mathrm{PCU}$ & NBPT \\
\hline \multicolumn{7}{|l|}{$M B C\left(m g k^{-1}\right)$} \\
\hline 0 & 104.08 & 113.80 & 106.28 & 103.05 & 102.75 & 98.50 \\
\hline 30 & 109.55 & 109.73 & 101.95 & 105.23 & 102.03 & 103.45 \\
\hline 60 & 106.75 & 110.93 & 126.50 & 114.85 & 111.33 & 116.75 \\
\hline 90 & 112.28 & 108.73 & 109.98 & 111.73 & 106.75 & 111.55 \\
\hline 120 & 119.70 & 114.45 & 115.63 & 117.68 & 120.65 & 118.85 \\
\hline \multicolumn{7}{|l|}{$M B N\left(m g k^{-1}\right)$} \\
\hline 0 & 26.80 & 26.87 & 24.45 & 29.45 & 28.75 & 26.26 \\
\hline 30 & 30.89 & 31.83 & 30.03 & 29.60 & 31.51 & 29.59 \\
\hline 60 & 36.10 & 36.42 & 33.58 & 35.48 & 36.50 & 35.48 \\
\hline 90 & 27.91 & 30.36 & 30.42 & 31.35 & 30.38 & 30.90 \\
\hline 120 & 31.92 & 34.67 & 34.13 & 31.35 & 30.06 & 33.62 \\
\hline \multicolumn{7}{|l|}{$\mathrm{C}-\mathrm{CO}_{2}\left(\mathrm{mg} \mathrm{kg}^{-1}\right)$} \\
\hline 0 & 7.21 & 6.78 & 6.58 & 8.00 & 8.15 & 8.82 \\
\hline 30 & 7.63 & 8.01 & 8.25 & 9.20 & 7.43 & 9.08 \\
\hline 60 & 8.57 & 7.30 & 9.23 & 7.88 & 8.35 & 8.14 \\
\hline 90 & 8.66 & 8.30 & 7.15 & 9.70 & 8.25 & 9.13 \\
\hline 120 & 8.00 & 8.15 & 8.82 & 8.80 & 8.58 & 7.95 \\
\hline \multicolumn{7}{|l|}{$q \mathrm{CO}_{2}\left(\mathrm{mg} \mathrm{kg}^{-1}\right)$} \\
\hline 0 & 0.058 & 0.068 & 0.063 & 0.090 & 0.070 & 0.095 \\
\hline 30 & 0.068 & 0.073 & 0.080 & 0.078 & 0.078 & 0.078 \\
\hline 60 & 0.080 & 0.068 & 0.073 & 0085 & 0.073 & 0.078 \\
\hline 90 & 0.078 & 0.078 & 0.065 & 0.073 & 0.073 & 0.075 \\
\hline 120 & 0.068 & 0.073 & 0.078 & 0.075 & 0.073 & 0.068 \\
\hline
\end{tabular}

Note UU: uncoated urea, PCU: polymer-coated urea, and NBPT: urease inhibitor NBPT-treated urea.

Applying $\mathrm{N}$ at rates above $60 \mathrm{~kg} \mathrm{ha}^{-1}$ exceeded the optimal $\mathrm{N}$ rate for microorganism activity, as indicated by the decrease in microbial respiration induced by the highest $\mathrm{N}$ rates (Figures $1 \mathrm{~b}, 1 \mathrm{c}$ and $2 \mathrm{c}$ ). Similar observations have been made before. In a 2-yr field experiment with a rain-fed rice cropping system, Oladele et al. (2019) reported that soil $\mathrm{CO}_{2}$ efflux was increased with the addition of $\mathrm{N}$ rates up to $60 \mathrm{~kg} \mathrm{ha}^{-1}$, above which microbial respiration decreased because of the inhibitory effect of excess $\mathrm{N}$. The results are also in line with Zhai et al. (2017) who found negative effects of $\mathrm{N}$ addition on microbial respiration in diverse land-use types after using solid granules of urea at varying $\mathrm{N}$ rates. An overall reduction in basal respiration with fertilization was also reported in five grassland ecosystems (Riggs et al., 2015; Strecker et al., 2015; Geisseler et al., 2016).

The decline in microbial $\mathrm{CO}_{2}$ production over the 2-yr experiment under high $\mathrm{N}$ rates is an evidence of any indirect effect of increased $\mathrm{N}$ availability on soil respiration. Recently, Zhang et al. (2019) found a decrease in microbial respiration under the addition of $100 \mathrm{~kg} \mathrm{~N} \mathrm{ha}^{-1}$ in the form of urea in a grassland soil. These authors attributed their results to the increased $\mathrm{C}$ input into the soil through litter decomposition and root exudates promoted by the increases in available $\mathrm{N}$, which in turn promotes plant growth and aboveground $\mathrm{C}$ accumulation. $\mathrm{Li}$ et al. (2015) have also observed that soil microbial respiration was adversely influenced by $\mathrm{N}$ addition due to the effect of $\mathrm{N}$ availability on soil $\mathrm{C}$ storage. It is well acknowledged that microbial activities in agricultural soils are mainly determined by $\mathrm{C}$ availability (Chantigny et al., 1999), revealing the importance of the regulatory effects of $\mathrm{N}$ fertilization on soil $\mathrm{C}$, which enhance aboveground plant biomass thus suppressing soil microbial biomass. 


\section{Conclusions}

Responses of soil microbial properties to $\mathrm{N}$ fertilization were dependent on the $\mathrm{N}$ rates, but no significant effect of the $\mathrm{N}$ sources was observed. All measured parameters, except $\mathrm{MBC}$ in the first season and $\mathrm{C}-\mathrm{CO}_{2}$ in the second season, were increased with increasing $\mathrm{N}$ rates. However, the application of $\mathrm{N}$ higher than $60 \mathrm{~kg} \mathrm{ha}^{-1}$ suppressed microbial biomass, as well as soil respiration. Therefore, the lack of response by added urease inhibitors to the $\mathrm{N}$ sources indicate that optimizing $\mathrm{N}$ rates for upland rice production is a far more effective option for improving soil microbial community than using enhanced-efficiency $\mathrm{N}$ sources.

\section{Acknowledgements}

To the National Council for Scientific and Technological Development (CNPq) for the granting of a doctoral scholarship to the first author, and to the Foundation for Research Support of the State of Goiás (FAPEG) for the granting of a postdoctoral fellowship to the third author.

\section{References}

Castro, A. P., Morais, O. P., Breseghello, F., Lobo, V. D. S., Guimarães, C. M., Bassinello, P. Z., ... Peters, V. J. (2014). BRS Esmeralda: Cultivar de arroz de terras altas com elevada produtividade e maior tolerância à seca. Comunicado Técnico (INFOTECA-E) Embrapa Arroz e Feijão: Goiânia, GO, Brazil.

Chantigny, M. H., Angers, D. A., Prévost, D., Simard, R. R., \& Chalifour, F. P. (1999). Dynamics of soluble organic $\mathrm{C}$ and $\mathrm{C}$ mineralization in cultivated soils with varying $\mathrm{N}$ fertilization. Soil Biol Biochem, 31(4), 543-550. https://doi.org/10.1016/S0038-0717(98)00139-4

Chien, S. H., Prochnow, L. I., \& Cantarella, H. (2008). Chapter 8 recent developments of fertilizer production and use to improve nutrient efficiency and minimize environmental impacts. Adv. Agron., 102, 267-322. https://doi.org/10.1016/S0065-2113(09)01008-6

Colombari Filho, J. M., Resende, M. D. V., Morais, O. P., Castro, A. P., Guimaraes, E. P., Pereira, J. A., ... Breseghello, F. (2013). Upland rice breeding in Brazil: A simultaneous genotypic evaluation of stability, adaptability and grain yield. Euphytica, 192(1), 117-129. https://doi.org/10.1007/s10681-013-0922-2

EMBRAPA (Empresa Brasileira de Pesquisa Agropecuária). (1997). Manual de métodos de análise de solo (2nd ed.). EMBRAPA-CNPS: Rio de Janeiro, R.J., Brazil.

EMBRAPA (Empresa Brasileira de Pesquisa Agropecuária). (2009). Manual de análises químicas de solos, plantas e fertilizantes (2nd ed.). Informação Tecnológica: Brasília, D.F., Brazil.

Engel, R. E., Romero, C. M., Carr, P., \& Torrion, J. A. (2019). Performance of nitrate compared with urea fertilizer in a semiarid climate of the northern Great Plains. Can. J. Soil Sci., 99(3), 345-355. https://doi.org/10.1139/cjss-2019-0047

Geisseler, D., Lazicki, P. A., \& Scow, K. M. (2016). Mineral nitrogen input decreases microbial biomass in soils under grasslands but not annual crops. Appl Soil Ecol., 106, 1-10. https://doi.org/10.1016/j.apsoil. 2016.04.015

Geisseler, D., \& Scow, K. M. (2014). Long-term effects of mineral fertilizers on soil microorganisms-A review. Soil Biol Biochem, 75, 54-63. https://doi.org/10.1016/j.soilbio.2014.03.023

Gioacchini, P., Nastri, A., Marzadori, C., Giovannini, C., Vittori Antisari, L., \& Gessa, C. (2002). Influence of urease and nitrification inhibitors on N losses from soils fertilized with urea. Biol. Fertil. Soils, 36, 129-135. https://doi.org/10.1007/s00374-002-0521-1

Krivtsov, V., Griffiths, B. S., Liddell, K., Garside, A., Salmond, R., Bezginova, T., \& Thompson, J. (2011). Soil nitrogen availability is reflected in the bacterial pathway. Pedosphere, 21(1), 26-30. https://doi.org/ 10.1016/S1002-0160(10)60075-6

Li, F., Liu, M., Li, Z., Jiang, C., Han, F., \& Che, Y. (2013). Changes in soil microbial biomass and functional diversity with a nitrogen gradient in soil columns. Appl Soil Ecol, 64, 1-6. https://doi.org/10.1016/ j.apsoil.2012.10.006

Li, Y., Liu, Y., Wu, S., Niu, L., Tian, Y. (2015). Microbial properties explain temporal variation in soil respiration in a grassland subjected to nitrogen addition. Sci. Rep., 5, 18496. https://doi.org/10.1038/srep18496

Liu, C., Gong, X., Dang, K., Li, J., Yang, P., Gao, X., ... Feng, B. (2020). Linkages between nutrient ratio and the microbial community in rhizosphere soil following fertilizer management. Environ. Res., 184, 109261. https://doi.org/10.1016/j.envres.2020.109261 
Lupwayi, N. Z., Clayton, G. W., O’Donovan, J. T., \& Grant, C. A. (2011). Soil microbial response to nitrogen rate and placement and barley seeding rate under no till. Agron. J., 103, 1064-1071. https://doi.org/ 10.2134/agronj2010.0334

Lupwayi, N. Z., Grant, C. A., Soon, Y. K., Clayton, G. W., Bittman, S., Malhi, S. S., \& Zebarth, B. J. (2010). Soil microbial community response to controlled-release urea fertilizer under zero tillage and conventional tillage. Appl. Soil Ecol., 45, 254-261. https://doi.org/10.1016/j.apsoil.2010.04.013

Lupwayi, N. Z., Lafond, G. P., Ziadi, N., \& Grant, C. A. (2012). Soil microbial response to nitrogen fertilizer and tillage in barley and corn. Soil Till Res, 118, 139-146. https://doi.org/10.1016/j.still.2011.11.006

Oladele, S., Adeyemo, A., Adegaiye, A., \& Awodun, M. (2019). Effects of biochar amendment and nitrogen fertilization on soil microbial biomass pools in an Alfisol under rain-fed rice cultivation. Biochar., 1(2), 163-176. https://doi.org/10.1007/s42773-019-00017-2

Ramirez, K. S., Craine, J. M., \& Fierer, N. (2010). Nitrogen fertilization inhibits soil microbial respiration regardless of the form of nitrogen applied. Soil Biol Biochem, 42, 2336-2338. https://doi.org/10.1016/ j.soilbio.2010.08.032

Riggs, C. E., Hobbie, S. E., Bach, E. M., Hofmockel, K. S., \& Kazanski, C. E. (2015). Nitrogen addition changes grassland soil organic matter decomposition. Biogeochemistry, 123, 203-219. https://oi.org/10.1007/ s10533-015-0123-2.

Santos, H. D., Jacomine, P. K. T., Anjos, L. D., Oliveira, V. D., Lumbreras, J. F., Coelho, M. R., ...Cunha, T. J. F. (2013). Sistema brasileiro de classificação de solos (p. 353). Embrapa Solos: Brasília, Brazil.

Singh, B. (2018). Are nitrogen fertilizers deleterious to soil health? Agronomy, 8(4), 48. https://doi.org/ 10.3390/agronomy8040048

Soil Survey Staff. (2014). Keys to Soil Taxonomy (12th ed.). U.S. Department of Agriculture, Natural Resources Conservation Service: Washington, D.C., United States.

Strecker, T., Barnard, R. L., Niklaus, P. A., Scherer-Lorenzen, M., Weigelt, A., Scheu, S., \& Eisenhauer, N. (2015). Effects of plant diversity, functional group composition, and fertilization on soil microbial properties in experimental grassland. PLoS One, 10(5), e0125678. https://doi.org/10.1371/journal.pone. 0125678

Vance E. D., Brookes P. C., \& Jenkinson, D. S. (1987). An extraction method for measuring soil microbial biomass C. Soil Bio Biochem, 19, 703-707. https://doi.org/10.1016/0038-0717(87)90052-6

Wardle, D. A. (1994). Metodologia para a quantificação da biomassa microbiana do solo. In M. Hungria \& R. S. Araújo (Eds.), Manual de métodos empregados em estudos de microbiologia agrícola (p. 542). Embrapa: Brasília, D.F., Brazil.

Yu, L., Yu, M., Lu, X., Tang, C., Liu, X., Brookes, P. C., \& Xu, J. (2018). Combined application of biochar and nitrogen fertilizer benefits nitrogen retention in the rhizosphere of soybean by increasing microbial biomass but not altering microbial community structure. Sci Total Environ, 640, 1221-1230. https://doi.org/ 10.1016/j.scitotenv.2018.06.018

Zhai, D., Jin, W., Shao, J., He, Y., Zhang, G., Li, M., ... Zhou, X. (2017). Different response patterns of soil respiration to a nitrogen addition gradient in four types of land-use on an alluvial island in China. Ecosystems, 20(5), 904-916. https://doi.org/10.1007/s10021-016-0079-7

Zhalnina, K., Dias, R., Quadros, P. D., Davis-Richardson, A., Camargo, F. A., Clark, I. M., ... Triplett, E. W. (2015). Soil pH determines microbial diversity and composition in the park grass experiment. Microb. Ecol., 69, 395-406. https://doi.org/10.1007/s00248-014-0530-2

Zhang, C., Song, Z., Zhuang, D., Wang, J., Xie, S., \& Liu, G. (2019). Urea fertilization decreases soil bacterial diversity, but improves microbial biomass, respiration, and $\mathrm{N}$-cycling potential in a semiarid grassland. Biology Fert Soils, 55(3), 229-242. https://doi.org/10.1007/s00374-019-01344-z

Zhang, N., Wan, S., Li, L., Bi, J., Zhao, M., \& Ma, K. (2008). Impacts of urea N addition on soil microbial community in a semi-arid temperate steppe in northern China. Plant Soil, 311, 19-28. https://doi.org/ $10.1007 / \mathrm{s} 11104-008-9650-0$

Zhou, X. B., Zhang, Y. M., \& Downing, A. (2012). Non-linear response of microbial activity across a gradient of nitrogen addition to a soil from the Gurbantunggut Desert, northwestern China. Soil Biol Biochem, 47, 67-77. https://doi.org/10.1016/j.soilbio.2011.05.012 


\section{Copyrights}

Copyright for this article is retained by the author(s), with first publication rights granted to the journal.

This is an open-access article distributed under the terms and conditions of the Creative Commons Attribution license (http://creativecommons.org/licenses/by/4.0/). 